Vol. 15 (2006): 219-234.

\title{
Omasal sampling technique in estimation of the site and extent of mineral absorption in dairy cows fed rapeseed and soybean expellers
}

\author{
Mikko Tuori, Marketta Rinne \\ MTT Agrifood Research Finland, Animal Production Research, FI-31600 Jokioinen, Finland, \\ e-mail:mikko.tuori@mtt.fi \\ Aila Vanhatalo \\ Department of Animal Science, PO Box 28, FI-00014 University of Helsinki, Finland \\ Pekka Huhtanen \\ MTT Agrifood Research Finland, Animal Production Research, FI-31600 Jokioinen, Finland
}

\begin{abstract}
The effects of rapeseed and soybean expeller on digestion of sodium, potassium, calcium, magnesium, phosphorus and sulphur in dairy cows were investigated in a study conducted as an incomplete Latin square. The experimental diets consisted of five concentrates fed at a rate of $9 \mathrm{~kg} \mathrm{~d}^{-1}$ : a mixture of barley and oats (control), which was replaced either with rapeseed or soybean expeller both at two levels (130, 180 and 230 $\mathrm{g}$ crude protein per $\mathrm{kg}$ dry matter). A mixture of grass and red clover silage (1:1) was fed ad libitum. No mineral supplements except for $\mathrm{NaCl}$ and trace minerals were used. Ruminal digestion was estimated by omasal sampling technique and total digestion from total faecal collection. Intake of all minerals except sodium increased with the level of protein supplementation and it was generally higher when rapeseed compared with soybean expeller diets were offered. Reticulo-rumen was the major site of net absorption of magnesium, whereas calcium, phosphorus, sodium and potassium were absorbed postruminally. Net absorption of sulphur took place both in the rumen and postruminally. Omasal flow of sodium and phosphorus indicated substantial secretion of these minerals into the rumen via saliva. Compared with the published data based on duodenal sampling, the results indicated that omasum has an important role in the absorption of minerals, especially sodium and phosphorus. Omasal sampling technique is a useful tool in studying ruminal mineral metabolism.
\end{abstract}

Key words: calcium, magnesium, potassium, phosphorus, sodium, sulphur, digestibility 
Tuori, M. et al. Omasal sampling to study mineral digestion

\section{Introduction}

Nutrition and feeding recommendations of minerals have traditionally been set to ensure sufficient supply with safety margin in all dietary circumstances. However, this approach can nowadays not be justified due to economic reasons, and especially because the nutrient losses from agriculture have become the most important factor causing eutrophication in surface waters (Valpasvuo-Jaatinen et al. 1997, Ekholm et al. 1999, Granlund et al. 2005). Eutrophication has many negative effects like growth of algae and aquatic weeds and reduced water transparency. Shifts in algae species composition towards cyanobacteria or blue-green algal dominance can produce toxins, odour and taste problems for water treatment (Carpenter et al. 1998, Nash and Haygarth 2005). Owing to the need to reduce especially phosphorus leaching in agriculture, reduction of $\mathrm{P}$ overfeeding is of special importance in milk production.

The extent of mineral absorption has traditionally been investigated using the total faecal collection method. The site of mineral absorption has generally been investigated using animals cannulated at different segments of the digestive tract. Duodenal sampling is the most common method used to estimate the net absorption from or secretion into the rumen. However, duodenal sampling technique ignores absorption of minerals from the omasum. Absorption of some minerals from the omasum can be considerable (Engelhardt and Hauffe 1975, Edrise et al. 1986), especially for adult cattle which have more developed omasum than young cattle or sheep (Mäkelä 1956, Church 1988). Poutiainen (1968) investigated the flow of $\mathrm{Na}$ and $\mathrm{K}$ through the reticulo-omasal orifice by estimating liquid outflow using polyethylene glycol as a liquid phase marker and analysing the concentrations of sodium $(\mathrm{Na})$ and potassium $(\mathrm{K})$ in rumen fluid. This approach may be appropriate for minerals flowing mainly in the liquid phase (e.g. Na), but unrepresentative sample composition can result in biased flow estimates of minerals partly associated with digesta solid phase.
Omasal sampling technique as described by Huhtanen et al. (1997) and modified by Ahvenjärvi et al. (2000) provides another alternative for investigating ruminal mineral metabolism. The method has successfully been used in investigating ruminal metabolism of nitrogen and carbohydrates (Ahvenjärvi et al. 1999, Choi et al. 2002, Reynal et al. 2003), and also in studying biohydrogenation of dietary fatty acids in the rumen (Shingfield et al. 2003). Because of difficulties in obtaining a representative sample from the digesta flowing into the omasal canal, advanced marker techniques are required for reliable estimation of nutrient flow from the rumen (Ahvenjärvi et al. 2003).

The first objective of the present study was to investigate the potential of omasal sampling technique in estimating the ruminal metabolism of macro minerals [calcium $(\mathrm{Ca})$, phosphorus $(\mathrm{P}), \mathrm{K}$, $\mathrm{Na}$, magnesium $(\mathrm{Mg})$ and sulphur $(\mathrm{S})]$. The second objective was to examine the effects of the level and type (rapeseed vs. soybean expeller) of protein supplementation on mineral metabolism of dairy cows fed a diet based on red clover-grass silage and cereal grains. The supply of most of the minerals varied greatly between the diets due to differences in mineral concentrations between rapeseed and soybean. The lowest supplies of phosphorus and calcium were below the requirements (MTT 2006), which is a prerequisite to truly determine the efficiency of mineral absorption. The effects of the diets on nitrogen and carbohydrate digestion will be published separately.

\section{Material and methods}

\section{Animals and diets}

The effects of increasing dietary crude protein (CP) concentration with rapeseed and soybean expeller (Mildola Ltd., Finland) on the site of mineral absorption were studied with five multiparous Finnish Ayrshire cows fitted with rumen cannulas (Bar Diamond, Inc., Parma, ID, USA). The cows weighed $654 \mathrm{~kg}$ (SD 63) and were on average 51 
Vol. 15 (2006): 219-234.

(SD 12.6) days in milk at the beginning of the experiment. Experimental design was an incomplete Latin square (five diets, five cows, and four 21 day periods). The cows were kept in tie stalls. They were fed twice daily at 0600 and 1800 , and milked at 0700 and 1700 .

The basal diet consisted of silage supplemented with a concentrate comprising of a mixture of barley and oats (1:1). The silage was prepared by mixing pure red clover (Trifolium pratense) silage and a timothy (Phleum pratense) and meadow fescue (Festuca pratensis) silage 1:1. Both silages were made from 1st cut. Silage was fed ad libitum during the first 14 days of each $21 \mathrm{~d}$ period allowing proportionally 0.05 to 0.10 for refusals. Daily allowances of silage and concentrates were divided to four equal portions and fed to cows at 0600, 0900, 1800 and 2000. During the sampling period from $\mathrm{d} 14$ to 21 the intake was restricted to 0.95 of the ad libitum consumption to avoid refusals. The five dietary treatments were the basal concentrate (Control; $9 \mathrm{~kg} \mathrm{~d}^{-1}$ ), which was gradually replaced with rapeseed expeller (RSE) or soybean expeller (SBE) at low (L) or high $(\mathrm{H})$ levels of inclusion. Subsequently, abbreviations C, RL, RH, SL and $\mathrm{SH}$ will be used for the five diets. Daily allowances of rapeseed expeller were $2.0(\mathrm{RL})$ and $4.0 \mathrm{~kg} \mathrm{~d}^{-1}$ (RH) and those of soybean expeller 1.45 (SL) and $2.9 \mathrm{~kg} \mathrm{~d}^{-1}(\mathrm{SH})$, respectively. All diets were supplemented with $1 \mathrm{~g} \mathrm{~d}^{-1}$ of a trace mineral and vitamin premix and $100 \mathrm{~g} \mathrm{~d}^{-1}$ of $\mathrm{NaCl}$. No other mineral supplements were given.

\section{Markers and digesta sampling}

To determine digesta flow entering the omasal canal, a triple-marker system (France and Siddons 1986) was used. Two external markers associated with the digesta liquid phase (CrEDTA) and small particle phase (Yb-acetate) were continuously infused into the rumen using a peristaltic pump (Watson-Marlow 502 S, Falmouth, UK). An internal marker, indigestible neutral detergent fibre, was used as large particle marker. On d 15 of each period, priming doses of CrEDTA (4.2 $\mathrm{g}$ of $\mathrm{Cr}$ ) and $\mathrm{Yb}$-acetate $(3.1 \mathrm{~g}$ of $\mathrm{Yb})$ were administered into the rumen via rumen cannulas to facilitate a rapid equilibrium of marker concentrations in the rumen. Thereafter a continuous infusion of CrEDTA

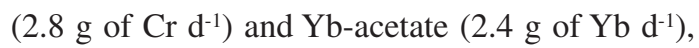
dissolved in 61 of distilled water, was administered until the end of each period.

To determine digesta flow, the samples were obtained from the omasal canal using a modification (Ahvenjärvi et al. 2000) of the sampling technique described by Huhtanen et al. (1997). Digesta samples $(400 \mathrm{ml})$ were collected on d 19 at 1, 4, 7 and $10 \mathrm{~h}$ after the morning feeding. On the two following days, the sampling time advanced $1 \mathrm{~h}$ each day, such that the samples represented each hour during the $12 \mathrm{~h}$ daytime feeding cycle. The samples were frozen immediately after sampling, and kept in $-20^{\circ} \mathrm{C}$ until thawed. Once thawed at room temperature the samples were pooled to form one sample per cow per period, divided into liquid, small particle and large particle phases as described by Ahvenjärvi et al. (2000).

Total digestibility was determined by total faecal collections on days 18-21 of each period. Urine was separated from faeces using a light harness attached around the vulva of each cow with an adhesive. Urine was drained into a container using a flexible tube. Urine $\mathrm{pH}$ was kept below 3 with $10 \mathrm{~N} \mathrm{H}_{2} \mathrm{SO}_{4}$.

\section{Chemical analysis}

Ash and crude protein of the feed, digesta and faecal samples were determined with standard methods (AOAC 1990). Neutral detergent fibre, silage fermentation quality and digesta flow markers were analysed as described by Ahvenjärvi et al. (2000). Mathematically calculated reconstitution factors, based on the triple marker system, were used to reconstitute the omasal canal digesta samples subjected for determination of mineral composition. Measurements of $\mathrm{Ca}, \mathrm{Mg}, \mathrm{P}, \mathrm{S}, \mathrm{K}$ and Na concentrations in feed, omasal, faecal and urine samples were performed with ICP emission spectrophotometer (Thermo Jarrel Ash/Baird, Franklin, USA) as described by Luh Huang and Schulte (1985). 
Tuori, M. et al. Omasal sampling to study mineral digestion

\section{Calculations and statistical analysis}

The flow of minerals to the omasal canal was calculated as DM flow $\left(\mathrm{kg} \mathrm{d}^{-1}\right) \times$ mineral concentration $\left(\mathrm{g} \mathrm{kg}^{-1} \mathrm{DM}\right)$. Apparent absorption in the rumen was calculated as difference between intake and omasal flow, and in the intestines as omasal flow - faecal output. The Lucas principle was used to test if the minerals were ideal nutritional entities. According to the Lucas principle, the true digestibility of a nutritional entity is determined as the slope of the regression between the concentration of digestible nutrient (e.g. crude protein, ether extract, and cell solubles) against the concentration of the nutrient (Lucas et al. 1964). The Lucas test was not applied for $\mathrm{Na}, \mathrm{K}$ and $\mathrm{Mg}$ because almost all $\mathrm{Na}$ was supplementary $\mathrm{NaCl}$ and the variations in dietary $\mathrm{K}$ and $\mathrm{Mg}$ concentrations were small.

Data was analysed with the GLM procedure of SAS (1999) using the following model: $Y_{\mathrm{ijk}}=\mu+$ $\mathrm{A}_{\mathrm{i}}+\mathrm{P}_{\mathrm{j}}+\mathrm{D}_{\mathrm{k}}+\mathrm{e}_{\mathrm{ijk}}$, where A, P and D are the animal, period and diet effects. Sums of squares of the diet effects were further divided into the following orthogonal comparisons: rapeseed vs. soybean expeller (RSE vs. SBE), linear and quadratic effects of protein supplementation and the interaction between protein source and level. The data presented in the tables are based on LS means. Paired t-test was used to estimate the differences in flow between sampling sites. Additionally, regression equations were calculated to describe mineral absorption at different sites of the digestive tract. A mixed model regression analysis with a random cow effect was used to estimate relationships between the intake and flow parameters. The P-values $<0.20$ of the statistical tests were reported in the tables. P-values of $0.10-0.05$ were considered a statistical trend and $\mathrm{P}$-values $<0.05$ were considered significant. When the P-values were smaller than 0.01 , they were reported as $\mathrm{P}<0.01$ irrespective of the level of significance.

\section{Results}

\section{Feed composition, DM intake and milk yield}

Chemical composition of the experimental feeds is presented in Table 1. Calcium concentration of silage was relatively high due to inclusion of red clover. Rapeseed expeller was higher in $\mathrm{Ca}, \mathrm{Mg}, \mathrm{P}$ and

Table 1. Composition of the experimental feeds.

\begin{tabular}{lcccc}
\hline & Silage $)^{1)}$ & Cereal grains $^{2)}$ & $\begin{array}{c}\text { Rapeseed } \\
\text { expeller }\end{array}$ & $\begin{array}{c}\text { Soybean } \\
\text { expeller }\end{array}$ \\
\hline $\begin{array}{l}\left.\text { Dry matter (DM, } \mathrm{g} \mathrm{kg}^{-1}\right) \\
\text { In dry matter }\left(\mathrm{g} \mathrm{kg}^{-1} \mathrm{DM}\right)\end{array}$ & 221 & 879 & 909 & 912 \\
Ash & 80 & 29 & 68 & 61 \\
Crude protein & 157 & 128 & 371 & 480 \\
Neutral detergent fibre & 498 & 213 & 312 & 213 \\
Sodium & 0.035 & 0.109 & 0.080 & 0.040 \\
Potassium & 26.8 & 5.3 & 12.7 & 23.3 \\
Calcium & 6.97 & 1.00 & 8.00 & 2.88 \\
Magnesium & 2.13 & 1.43 & 4.66 & 3.12 \\
Phosphorus & 2.86 & 4.16 & 10.54 & 6.10 \\
Sulphur & 2.12 & 1.63 & 6.39 & 3.91 \\
\hline
\end{tabular}

1) Silage was prepared by mixing pure red clover silage and timothy-meadow fescue silage $1: 1$. Silage in vitro D-value $668 \mathrm{~g} \mathrm{~kg}^{-1} \mathrm{DM}$, pH 3.95, ammonia-N $53 \mathrm{~g} \mathrm{~kg}^{-1}$ total $\mathrm{N}$, lactic acid $29 \mathrm{~g} \mathrm{~kg}^{-1} \mathrm{DM}$, acetic acid $14 \mathrm{~g} \mathrm{~kg}^{-1} \mathrm{DM}$ and butyric acid $0.3 \mathrm{~g} \mathrm{~kg}^{-1} \mathrm{DM}$.

${ }^{2)}$ Ground barley and oats 1:1. 
Vol. 15 (2006): 219-234.

S compared with soybean expeller, which contained more K. Dry matter intake was 19.7, 21.5, 21.8, 20.3 and 20.7 (SEM 0.46) $\mathrm{kg} \mathrm{d}^{-1}$ for diets C, RL, RH, SL and $\mathrm{SH}$, respectively. Intake was significantly $(\mathrm{P}<$ 0.05) higher for the RSE diets than for the SBE diets, and it increased linearly with the level of protein supplementation. The mean energy corrected milk yield of the cows followed a similar pattern being 31.1, 34.0, 34.5, 32.2 and 32.4 (SEM 0.57) kg d ${ }^{-1}$ for the diets $\mathrm{C}, \mathrm{RL}, \mathrm{RH}, \mathrm{SL}$ and $\mathrm{SH}$, respectively.

\section{Sodium digestion}

The influence of the protein supplements on the flow and excretion parameters of different minerals is presented in Tables 2-4. The mean dietary $\mathrm{Na}$ intake $\left(40.5 \mathrm{~g} \mathrm{~d}^{-1}\right)$ was almost entirely derived from supplementary $\mathrm{NaCl}$ (Table 2). On average, omasal
Na flow exceeded Na intake by $984 \mathrm{~g} \mathrm{~d}^{-1}$ indicating an extensive contribution of $\mathrm{Na}$ recycled via saliva to the $\mathrm{Na}$ flow from the rumen. Omasal $\mathrm{Na}$ flow was higher $(\mathrm{P}<0.01)$ in cows fed RSE diets than in those fed SBE diets, and it decreased with the level of protein supplementation $(\mathrm{P}<0.05)$. The decrease was greater for SBE than for RSE diets (interaction $\mathrm{P}<0.05)$. Faecal Na output and total digestibility were not significantly affected by the diet.

\section{Potassium digestion}

Potassium intake increased linearly $(\mathrm{P}<0.01)$ with the level of protein supplementation mainly due to increased silage DM intake. Omasal $\mathrm{K}$ flow was similar to $\mathrm{K}$ intake (418 vs. $414 \mathrm{~g} \mathrm{~d}^{-1} ; \mathrm{P}>0.10$ ). Ruminal and total absorption of potassium increased with the level of protein supplementation $(\mathrm{P}<0.01)$.

Table 2. The influence of protein supplements on the intake, flow, site of absorption $\left(\mathrm{g} \mathrm{d}^{-1}\right)$ and digestibility of sodium and potassium.

\begin{tabular}{|c|c|c|c|c|c|c|c|c|c|c|}
\hline & \multirow{2}{*}{ Control } & \multicolumn{2}{|c|}{ Rapeseed expeller } & \multicolumn{2}{|c|}{ Soybean expeller } & \multirow{2}{*}{ SEM } & \multicolumn{4}{|c|}{ Siqnificance $^{1)}(\mathrm{P}$-value $)$} \\
\hline & & Low & High & Low & High & & R vs. $S$ & Linear & Quadr. & Prot $\times$ Lin. \\
\hline \multicolumn{11}{|l|}{ Sodium } \\
\hline Intake & 40.5 & 40.6 & 40.6 & 40.5 & 40.4 & 0.1 & 0.03 & & 0.18 & 0.05 \\
\hline Omasal flow & 1046 & 1103 & 1018 & 994 & 959 & 17.3 & $<0.01$ & 0.03 & 0.09 & 0.04 \\
\hline Faecal excretion & 18.1 & 27.4 & 20.3 & 21.7 & 20.8 & 3.35 & & & 0.13 & \\
\hline \multicolumn{11}{|l|}{ Absorption } \\
\hline Reticulo-rumen & -1006 & -1062 & -977 & -954 & -918 & 17.4 & $<0.01$ & 0.03 & 0.09 & 0.05 \\
\hline Postruminal & 1028 & 1075 & 997 & 973 & 938 & 18.2 & $<0.01$ & 0.03 & 0.16 & 0.05 \\
\hline Total (net) & 22.4 & 13.2 & 20.3 & 18.8 & 19.6 & 3.3 & & & 0.13 & \\
\hline Apparent digestibility & 0.554 & 0.324 & 0.500 & 0.464 & 0.484 & 0.082 & & & 0.13 & \\
\hline \multicolumn{11}{|l|}{ Potassium } \\
\hline Intake & 379 & 414 & 437 & 398 & 442 & 9.6 & & $<0.01$ & & \\
\hline Omasal flow & 407 & 425 & 443 & 400 & 413 & 10.5 & 0.03 & 0.14 & & 0.08 \\
\hline Faecal excretion & 85.3 & 95.3 & 99.1 & 95.0 & 84.1 & 4.00 & 0.09 & & 0.11 & 0.03 \\
\hline \multicolumn{11}{|l|}{ Absorption } \\
\hline Reticulo-rumen & -28.6 & -11.3 & -6.4 & -1.9 & 29.1 & 8.3 & 0.03 & $<0.01$ & & 0.02 \\
\hline Postruminal & 322 & 330 & 344 & 305 & 329 & 11.2 & 0.12 & & & \\
\hline Total (net) & 293 & 318 & 338 & 303 & 358 & 9.6 & & $<0.01$ & & 0.17 \\
\hline Apparent digestibility & 0.770 & 0.767 & 0.773 & 0.759 & 0.808 & 0.012 & & 0.18 & 0.15 & 0.06 \\
\hline
\end{tabular}

${ }^{1)} \mathrm{R}$ vs. S = The effect of protein source (rapeseed expeller vs. soybean expeller), Linear = Linear effect of increasing protein supplementation, Quadr. = Quadratic effect of increasing protein supplementation, Prot $\times$ Lin. $=$ Interaction between the effect of protein source and linear effect of increasing protein supplementation. 
Tuori, M. et al. Omasal sampling to study mineral digestion

The total K digestibility averaged 0.775 and was not significantly influenced by diet (Table 2).

\section{Calcium digestion}

Calcium intake increased $(\mathrm{P}<0.01)$ with protein supplementation the effect being greater for RSE than SBE diets (interaction $\mathrm{P}<0.01$ ) (Table 3). Calcium flow to the omasal canal showed a similar pattern as the intake. Omasal Ca flow tended $(\mathrm{P}<$ 0.09) to be smaller than Ca intake (106.2 vs. 108.7 $\mathrm{g} \mathrm{d}^{-1}$ ) suggesting some net absorption of $\mathrm{Ca}$ from the rumen. Postruminal and total $\mathrm{Ca}$ absorption was higher in cows fed RSE than in those fed SBE. Because the differences in $\mathrm{Ca}$ digestibility were small, faecal $\mathrm{Ca}$ excretion increased $(\mathrm{P}<0.01)$ with protein supplementation, and it was higher (P $<0.01$ ) for RSE than SBE diets. Total Ca digestibility was not influenced by the diet.
Intercept of the regression between $\mathrm{Ca}$ intake and omasal flow was slightly positive and slope slightly below 1.00 , but neither the intercept nor the slope were significantly different from zero or one (Table 5). The relationships between Ca intake (and flow) and net absorption were much weaker than those between intake and omasal flow vs. faecal excretion. The parameters of the Lucas test indicate that calcium is not an ideal nutritional entity.

\section{Magnesium digestion}

Due to the differences in $\mathrm{Mg}$ concentration of feeds and total DM intake, $\mathrm{Mg}$ intake was higher $(\mathrm{P}<0.01)$ in cows consuming RSE diets than in those consuming SBE diets and it increased $(\mathrm{P}<$ $0.01)$ linearly with the level of protein supplementation (Table 3). Similar pattern of differences was observed for omasal $\mathrm{Mg}$ flow and faecal Mg out-

Table 3. The influence of protein supplements on the intake, flow, site of absorption $\left(\mathrm{g} \mathrm{d}^{-1}\right)$ and digestibility of calcium and magnesium.

\begin{tabular}{|c|c|c|c|c|c|c|c|c|c|}
\hline & \multirow{2}{*}{ Control } & \multicolumn{2}{|c|}{ Rapeseed expeller } & \multicolumn{2}{|c|}{ Soybean expeller } & \multirow{2}{*}{ SEM } & \multicolumn{3}{|c|}{ Siqnificance $^{1)}(\mathrm{P}$-value $)$} \\
\hline & & Low & High & Low & High & & R vs. $S$ & Linear & Prot $\times$ Lin \\
\hline \multicolumn{10}{|l|}{ Calcium } \\
\hline Intake & 96.2 & 115.0 & 131.1 & 96.9 & 104.2 & 2.5 & $<0.01$ & $<0.01$ & $<0.01$ \\
\hline Omasal flow & 92.8 & 111.9 & 128.1 & 96.1 & 102.2 & 1.2 & $<0.01$ & $<0.01$ & $<0.01$ \\
\hline Faecal excretion & 64.2 & 75.6 & 89.0 & 64.1 & 67.6 & 3.1 & $<0.01$ & $<0.01$ & $<0.01$ \\
\hline \multicolumn{10}{|l|}{ Absorption } \\
\hline Reticulo-rumen & 3.4 & 3.1 & 3.1 & 0.8 & 2.0 & 2.3 & & & \\
\hline Postruminal & 28.5 & 36.4 & 39.1 & 32.0 & 34.6 & 2.6 & 0.12 & 0.03 & \\
\hline Total (net) & 32.0 & 39.5 & 42.1 & 32.7 & 36.5 & 2.5 & 0.04 & 0.04 & 0.15 \\
\hline Apparent digestibility & 0.335 & 0.342 & 0.324 & 0.339 & 0.359 & 0.022 & & & \\
\hline \multicolumn{10}{|l|}{ Magnesium } \\
\hline Intake & 37.1 & 46.5 & 53.5 & 40.1 & 43.8 & 0.8 & $<0.01$ & $<0.01$ & $<0.01$ \\
\hline Omasal flow & 28.9 & 37.1 & 43.1 & 29.9 & 31.9 & 0.89 & $<0.01$ & $<0.01$ & $<0.01$ \\
\hline Faecal excretion & 28.4 & 37.4 & 42.8 & 30.6 & 34.1 & 1.19 & $<0.01$ & $<0.01$ & $<0.01$ \\
\hline \multicolumn{10}{|l|}{ Absorption } \\
\hline Reticulo-rumen & 8.2 & 9.5 & 10.4 & 10.2 & 11.8 & 1.0 & & 0.04 & \\
\hline Postruminal & 0.6 & -0.4 & 0.3 & -0.70 & -2.20 & 0.66 & 0.07 & 0.10 & 0.03 \\
\hline Total (net) & 8.7 & 9.1 & 10.7 & 9.5 & 9.7 & 1.0 & & & \\
\hline Apparent digestibility & 0.237 & 0.194 & 0.200 & 0.237 & 0.222 & 0.021 & 0.17 & & \\
\hline
\end{tabular}

${ }^{1)} \mathrm{R}$ vs. $\mathrm{S}=$ The effect of protein source (rapeseed expeller vs. soybean expeller), Linear = Linear effect of increasing protein supplementation, Quadr. = Quadratic effect of increasing protein supplementation, Prot $\times$ Lin. $=$ Interaction between the effect of protein source and linear effect of increasing protein supplementation. 
Vol. 15 (2006): 219-234.

put. Omasal and faecal $\mathrm{Mg}$ flow $\left(\mathrm{g} \mathrm{d}^{-1}\right)$ were closely related to $\mathrm{Mg}$ intake $\left(\mathrm{g} \mathrm{d}^{-1}\right)$ as indicated by the following regression equations:

Omasal $\mathrm{Mg}=-5.1 \pm 4.8+0.89 \pm 0.11 \mathrm{Mg}$ intake (Se. est. $\left.=2.78 ; \mathrm{R}^{2}=0.80\right)$

Faecal $\mathrm{Mg}=-4.5 \pm 3.4+0.89 \pm 0.08 \mathrm{Mg}$ intake (Se. est. $\left.=2.10 ; \mathrm{R}^{2}=0.87\right)$

Absorption of $\mathrm{Mg}$ from the rumen increased linearly $(\mathrm{P}<0.01)$ as the protein concentration of the supplement increased. However, because of the variable post-ruminal net absorption, the differences in total absorption did not reach significance.

\section{Phosphorus digestion}

Phosphorus intake (Table 4) increased $(\mathrm{P}<0.01)$ with protein supplemented diets, and it was higher
$(\mathrm{P}<0.01)$ with diets containing RSE than with those containing SBE. Phosphorus flow to the omasal canal and excretion in faeces showed similar patterns to those observed in the intake. As a result of ruminal secretion of $\mathrm{P}$, omasal $\mathrm{P}$ flow was on average about twice greater than the intake. Apparent absorption in the rumen or postruminally was not influenced by the diet. The total (net) absorption was higher $(\mathrm{P}<0.05)$ for the cows fed the RSE diets than for those fed the SBE diets, and it increased linearly $(\mathrm{P}<0.01)$ with the level of protein supplementation.

There was a strong positive correlation between $\mathrm{P}$ intake, $\mathrm{P}$ flow into the omasum and faecal $\mathrm{P}$ excretion (Table 5). The relationship between $\mathrm{P}$ intake and omasal $\mathrm{P}$ flow was very similar to that based on individual cow data when calculated using treatment means: P flow $\left(\mathrm{g} \mathrm{d}^{-1}\right)=82.3+1.08 \times$ $\mathrm{P}$ intake $\left(\mathrm{g} \mathrm{d}^{-1} ; \mathrm{R}^{2}=0.94\right)$. Linear relationships be-

Table 4. The influence of protein supplements on the intake, flow, site of absorption $\left(\mathrm{g} \mathrm{d}^{-1}\right)$ and digestibility of phosphorus and sulphur.

\begin{tabular}{|c|c|c|c|c|c|c|c|c|c|c|}
\hline & \multirow{2}{*}{ Control } & \multicolumn{2}{|c|}{ Rapeseed expeller } & \multicolumn{2}{|c|}{ Soybean expeller } & \multirow{2}{*}{ SEM } & \multicolumn{4}{|c|}{ Siqnificance (P-value) } \\
\hline & & Low & High & Low & High & & R vs. $\mathrm{S}$ & Linear & Quadr. & Prot $\times$ Lin. \\
\hline \multicolumn{11}{|l|}{ Phosphorus } \\
\hline Intake & 65.3 & 85.0 & 98.3 & 71.3 & 75.1 & 1.7 & $<0.01$ & $<0.01$ & & $<0.01$ \\
\hline Omasal flow & 150 & 179 & 187 & 163 & 163 & 4.8 & $<0.01$ & $<0.01$ & 0.10 & $<0.01$ \\
\hline Faecal excretion & 39.0 & 51.6 & 61.2 & 42.2 & 43.2 & 2.46 & $<0.01$ & $<0.01$ & & $<0.01$ \\
\hline \multicolumn{11}{|l|}{ Absorption } \\
\hline Reticulo-rumen & -85.1 & -94.4 & -88.4 & -91.9 & -88.2 & 4.8 & & & 0.19 & \\
\hline Postruminal & 111.3 & 127.7 & 125.5 & 120.9 & 120.1 & 4.06 & 0.17 & 0.05 & 0.10 & \\
\hline Total (net) & 26.3 & 33.3 & 37.1 & 29.0 & 31.9 & 1.5 & 0.01 & $<0.01$ & & 0.04 \\
\hline Apparent digestibility & 0.407 & 0.391 & 0.379 & 0.407 & 0.427 & 0.021 & 0.16 & & & 0.15 \\
\hline \multicolumn{11}{|l|}{ Sulphur } \\
\hline Intake & 38.3 & 51.1 & 61.1 & 42.5 & 46.9 & 0.8 & $<0.01$ & $<0.01$ & & $<0.01$ \\
\hline Omasal flow & 32.0 & 40.8 & 47.4 & 35.7 & 38.8 & 1.27 & $<0.01$ & $<0.01$ & & $<0.01$ \\
\hline Faecal excretion & 20.0 & 25.7 & 28.2 & 21.7 & 22.4 & 0.61 & $<0.01$ & $<0.01$ & 0.11 & $<0.01$ \\
\hline \multicolumn{11}{|l|}{ Absorption } \\
\hline Reticulo-rumen & 6.3 & 10.3 & 13.7 & 6.7 & 8.1 & 1.3 & $<0.01$ & 0.02 & & 0.02 \\
\hline Postruminal & 12.0 & 15.1 & 19.2 & 14.0 & 16.30 & 0.99 & 0.08 & $<0.01$ & & 0.08 \\
\hline Total (net) & 18.4 & 25.4 & 32.9 & 20.8 & 24.5 & 0.6 & $<0.01$ & $<0.01$ & & $<0.01$ \\
\hline Apparent digestibility & 0.479 & 0.497 & 0.538 & 0.490 & 0.523 & 0.008 & 0.20 & $<0.01$ & 0.14 & \\
\hline
\end{tabular}

${ }^{1)} \mathrm{R}$ vs. $\mathrm{S}=$ The effect of protein source (rapeseed expeller vs. soybean expeller), Linear = Linear effect of increasing protein supplementation, Quadr. = Quadratic effect of increasing protein supplementation, Prot $\times$ Lin. $=$ Interaction between the effect of protein source and linear effect of increasing protein supplementation. 


\section{AGRICULTURAL AND FOOD SCIENCE}

Tuori, M. et al. Omasal sampling to study mineral digestion

tween daily $\mathrm{P}$ intake or $\mathrm{P}$ flow and apparent absorption of $\mathrm{P}$ were observed. When the Lucas principle was applied for $\mathrm{P}$ intake, the intercept was positive $(\mathrm{P}>0.05)$ and the slope (true digestibility) was only 0.29 . However, when the same test was made for the omasal $\mathrm{P}$ flow, the intercept was negative $(\mathrm{P}>0.05)$ and the slope markedly higher (0.80).

\section{Sulphur digestion}

Sulphur intake increased $(\mathrm{P}<0.01)$ with the level of protein supplementation and was higher $(\mathrm{P}<$ $0.01)$ in the cows consuming RSE diets than in those consuming SBE diets (Table 4). Similar pattern of differences between the diets was observed in omasal flow and faecal excretion. Apparent absorption of sulphur from the rumen was higher ( $\mathrm{P}$ $<0.01$ ) for RSE fed cows than for SBE fed cows, and it increased linearly $(\mathrm{P}<0.01)$ with protein supplementation. The latter effect was stronger for RSE compared with SBE diets (interaction $\mathrm{P}<$ 0.01). Total sulphur digestibility increased $(\mathrm{P}<$ 0.01 ) with the level of protein supplementation.

Omasal flow and faecal excretion of sulphur were closely related $(\mathrm{P}<0.01)$ to $\mathrm{S}$ intake (Table 5). Regressions of faecal $S$ output on $S$ intake or omasal $\mathrm{S}$ flow had positive intercepts suggesting that faecal $S$ had a metabolic and endogenous component. Applying the Lucas test for sulphur indicated a significantly $(\mathrm{P}<0.01)$ negative intercept and a slope with relatively low standard error. There was a close relationship between faecal $\mathrm{N}$ and $\mathrm{S}$ excretion $\left(\mathrm{R}^{2}=0.91\right)$.

\section{Discussion}

\section{Experimental methods}

Omasal sampling technique provides some advantages compared with duodenal sampling in estimating mineral metabolism in the reticulo-rumen as problems associated with absorption from the omasum will be avoided. However, a potential source of error in the omasal sampling technique is the difficulty in obtaining representative samples of the omasal digesta. Minerals are distributed differently between rumen digesta fractions (Joblin and Lee 1990), and therefore unrepresentative digesta sample composition will result in biased mineral flow estimates, both due to erroneous DM flow estimates and mineral concentrations. Sodium and potassium are almost entirely in the rumen liquid phase, whereas $\mathrm{Ca}, \mathrm{Mg}, \mathrm{P}$ and $\mathrm{S}$ are present in both liquid and solid phases of the digesta with majority of $\mathrm{P}$ and $\mathrm{Mg}$ in the liquid phase, and $\mathrm{Ca}$ and $\mathrm{S}$ in the particulate fraction, respectively (Joblin and Lee 1990).

We used a triple-marker technique (France and Siddons 1986) to reduce the possibility of biased flow estimates resulting from unrepresentative sampling. The effect of unrepresentative sampling on the marker concentration relative to individual chemical component is dependent on the association between the two (Ahvenjärvi et al. 2003). In the case that a marker is closely associated with a specific chemical component, unrepresentative sampling will influence the marker concentration in DM, but not on the ratio of the marker and chemical component. Consequently, unrepresentative sampling would influence DM flow, but not that of the chemical component to which the marker is associated with. For example, using only a liquid phase marker may result in biased DM flow estimate, but due to the close association between the marker and liquid phase minerals ( $\mathrm{Na}$ and $\mathrm{K}$ ), the flow can be estimated accurately.

The method used by Poutiainen (1968), i.e. determining liquid passage rate and rumen volume using polyethylene glycol and the concentrations of $\mathrm{Na}$ and $\mathrm{K}$ are less susceptible to experimental errors. In contrast, estimation of $\mathrm{Na}$ or $\mathrm{K}$ flow from the fore-stomachs by using a solid phase marker can result in severely biased flow estimates because of two reasons: unrepresentative sampling causes errors both in DM flow estimate and mineral concentrations. For example, if a single marker system based on a particle marker is used and the digesta sample contains too much particle phase, both true DM flow and $\mathrm{Na}$ (and $\mathrm{K}$ ) concentrations are under- 
Vol. 15 (2006): 219-234.

Table 5. Regression equations for the flow and absorption of calcium, phosphorus and sulphur $\left(\mathrm{g} \mathrm{d}^{-1}\right)$, and the Lucas tests ( $\mathrm{Y}=$ digestible mineral content $\left(\mathrm{g} \mathrm{kg}^{-1} \mathrm{DM}\right)$ and $\mathrm{X}=$ mineral content in the $\operatorname{diet}\left(\mathrm{g} \mathrm{kg}^{-1} \mathrm{DM}\right)$ ).

\begin{tabular}{|c|c|c|c|c|c|c|c|c|c|}
\hline Y variable & $\mathrm{X}$ variable & Intercept & s.e. & P-value & $\begin{array}{c}\text { Regression } \\
\text { coefficient }\end{array}$ & s.e. & P-value & RMSE & $\mathrm{R}^{2}$ \\
\hline \multicolumn{10}{|l|}{ Calcium } \\
\hline Omasal flow & Intake & 5.1 & 9.44 & 0.62 & 0.93 & 0.084 & $<0.01$ & 4.77 & 0.907 \\
\hline Faecal excretion & Intake & -15.8 & 8.46 & 0.14 & 0.81 & 0.077 & $<0.01$ & 4.90 & 0.874 \\
\hline Faecal excretion & Omasal flow & -10.0 & 8.76 & 0.32 & 0.77 & 0.078 & $<0.01$ & 4.31 & 0.897 \\
\hline \multicolumn{10}{|l|}{ Absorbed } \\
\hline Total & Intake & 15.8 & 8.46 & 0.14 & 0.19 & 0.077 & 0.03 & 4.90 & 0.254 \\
\hline Postruminal & Omasal flow & 10.0 & 8.76 & 0.32 & 0.23 & 0.078 & $<0.01$ & 4.31 & 0.413 \\
\hline \multicolumn{10}{|l|}{ Phosphorus } \\
\hline Omasal flow & Intake & 85.1 & 12.50 & $<0.01$ & 1.06 & 0.152 & $<0.01$ & 7.26 & 0.762 \\
\hline Faecal excretion & Intake & -11.2 & 4.61 & 0.07 & 0.74 & 0.058 & $<0.01$ & 3.11 & 0.897 \\
\hline Faecal excretion & Omasal flow & -42.4 & 12.67 & 0.03 & 0.53 & 0.074 & $<0.01$ & 4.33 & 0.897 \\
\hline \multicolumn{10}{|l|}{ Absorbed } \\
\hline Total & Intake & 11.2 & 4.61 & 0.07 & 0.26 & 0.058 & $<0.01$ & 3.11 & 0.500 \\
\hline Postruminal & Omasal flow & 42.4 & 12.67 & 0.03 & 0.47 & 0.074 & $<0.01$ & 4.33 & 0.745 \\
\hline \multicolumn{10}{|l|}{ Sulphur } \\
\hline Omasal flow & Intake & 7.4 & 4.33 & 0.16 & 0.66 & 0.088 & $<0.01$ & 2.97 & 0.762 \\
\hline Faecal excretion & Intake & 4.8 & 1.78 & 0.06 & 0.39 & 0.037 & $<0.01$ & 1.34 & 0.897 \\
\hline Faecal excretion & Omasal flow & 5.7 & 2.77 & 0.05 & 0.46 & 0.070 & $<0.01$ & 1.99 & 0.897 \\
\hline \multicolumn{10}{|l|}{ Absorbed } \\
\hline Total & Intake & -4.8 & 1.78 & 0.06 & 0.61 & 0.037 & $<0.01$ & 1.34 & 0.936 \\
\hline Postruminal & Omasal flow & -5.7 & 2.77 & 0.11 & 0.54 & 0.070 & $<0.01$ & 1.99 & 0.754 \\
\hline Faecal S & Faecal N & -8.2 & 2.53 & 0.03 & 0.16 & 0.013 & $<0.01$ & 1.05 & 0.914 \\
\hline \multicolumn{10}{|l|}{ Lucas tests } \\
\hline Digestible $\mathrm{Ca}$ & $\mathrm{Ca}$ & 0.16 & 0.587 & 0.80 & 0.31 & 0.111 & $<0.01$ & 0.246 & 0.308 \\
\hline Digestible P & $\mathrm{P}$ & 0.40 & 0.329 & 0.29 & 0.29 & 0.086 & $<0.01$ & 0.165 & 0.360 \\
\hline Digestible S & $\mathrm{S}$ & -0.40 & 0.095 & $<0.01$ & 0.68 & 0.041 & $<0.01$ & 0.056 & 0.936 \\
\hline
\end{tabular}

RMSE is an estimate of the standard deviation of the error term in the model.

estimated, which can lead to severe underestimation of $\mathrm{Na}$ (and $\mathrm{K}$ ) flow. These methodological aspects have very seldom been considered in studies investigating mineral absorption from different sites of the digestive tract.

\section{Sodium}

The mean Na flow of $1024 \mathrm{~g} \mathrm{~d}^{-1}$ to the omasal canal was almost 25 -fold compared with the sodium intake $\left(40.5 \mathrm{~g} \mathrm{~d}^{-1}\right)$ reflecting net salivary Na secre- tion into the rumen. In the present study, omasal Na flow was markedly higher than in studies using duodenal sampling. At the sodium intake of $61 \mathrm{~g}$ $\mathrm{d}^{-1}$ the duodenal flow was 4.5 -fold (Rahnema et al. 1994) and at the intake of $106 \mathrm{~g}$ sodium per day the duodenal flow was 2.1-fold (Khorasani et al. 1997). Using omasal sampling the $\mathrm{Na}$ flow to the omasum was 17 -fold at the intake of $34 \mathrm{~g} \mathrm{~d}^{-1}$ in ruminating calves (Edrise et al. 1986). Although the higher DM intake may have contributed to the higher $\mathrm{Na}$ secretion in the rumen in the present study, most of the difference between the studies can be attributed 
Tuori, M. et al. Omasal sampling to study mineral digestion

to different sampling sites. Appreciable absorption of sodium from the omasum of both sheep and cattle has been reported. Engelhardt and Hauffe (1975) measured omasal absorption of sodium in sheep to be $26 \%$ and Edrise et al. (1986) reported a range of $40-60 \%$ in young cattle. Faecal $\mathrm{Na}$ output was not related to omasal Na flow [Faecal $(\mathrm{Na}$ $\left.\mathrm{g} \mathrm{d}^{-1}\right)=14.0 \pm 19.2+0.008 \pm(0.0187) \times$ Omasal Na $\left.\left(\mathrm{g} \mathrm{d}^{-1}\right)\right]$ indicating that $\mathrm{Na}$ secreted via saliva into the rumen was completely reabsorbed. The omasal $\mathrm{Na}$ flow was greater in cows receiving RSE compared to those on SBE diets, but the difference was quantitatively relatively small and possibly related to differences in feed intake.

Salivary Na concentration seems to be much less variable than that of phosphorus and therefore saliva production may be estimated from net $\mathrm{Na}$ secretion and $\mathrm{Na}$ concentrations in saliva. Using the mean salivary $\mathrm{Na}$ concentration of $160 \mathrm{mmol}$ $1^{-1}$ (Poutiainen 1968, Van Soest 1994, Sjaastadt et al. 2003) and salivary $\mathrm{Na}$ secretion of $982 \mathrm{~g} \mathrm{~d}^{-1}$ gives an estimate of $267 \mathrm{~d} \mathrm{~d}^{-1}$ for the saliva production, which is comparable of the measured saliva flow of $239 \mathrm{ld}^{-1}$ when the cows were eating 18.2 $\mathrm{kg} \mathrm{DM} \mathrm{d}{ }^{-1}$ at forage:concentrate ratio of 60:40 (Maekawa et al. 2002). In the present study, salivary Na flow per $\mathrm{kg}$ DM intake was slightly higher (47.2 g) than the corresponding value calculated from the data of Poutiainen $(38.3 \mathrm{~g})$.

Assuming that the rumen volume of these cows was similar to that measured in our recent studies in cows fed similar diets ( $801 ; \mathrm{n}=13$, unpublished data from MTT), the mean liquid outflow rate would be $0.138 \mathrm{~h}^{-1}$. However, Na concentration in the rumen fluid is lower than in saliva due to dilution by water drunk and contained in feeds so that total liquid outflow and outflow rate would be higher. Assuming that $\mathrm{Na}$ concentration in rumen fluid was 20\% lower than in saliva (Poutiainen 1968) liquid outflow and passage rate had been $334 \mathrm{ld}^{-1}$ and $0.173 \mathrm{~h}^{-1}$, respectively.

\section{Potassium}

On average, no net $\mathrm{K}$ absorption from the rumen was observed in the present study. However, Rah- nema et al. (1994) and Khorasani et al. (1997) reported pre-intestinal absorption of $\mathrm{K}$. This difference may be attributed to absorption from the omasum (Engelhardt and Hauffe 1975, Edrise et al. 1986). Ruminal outflow of $\mathrm{K}$ was higher with RSE than SBE supplementation, which could be related to increased silage DM intake. Total $\mathrm{K}$ absorption was strongly related $\left(\mathrm{R}^{2}=0.95\right)$ to $\mathrm{K}$ intake. Ruminal and postruminal $\mathrm{K}$ absorption was only moderately related to $\mathrm{K}$ intake $\left(\mathrm{R}^{2}=0.37\right.$ and 0.28 ), whereas postruminal $\mathrm{K}$ absorption was strongly $\left(\mathrm{R}^{2}=0.94\right)$ influenced by omasal K flow.

In addition to dietary intake, $\mathrm{K}$ is secreted in variable concentrations into the rumen via saliva (see Van Soest 1994). Using a concentration of 10 mmol $\mathrm{l}^{-1}$ (Van Soest) would result in a salivary $\mathrm{K}$ secretion of about $100 \mathrm{~g} \mathrm{~d}^{-1}$. Because the apparent absorption of $\mathrm{K}$ from the rumen was close to zero, true absorption of $\mathrm{K}$ was equal to salivary secretion. Salivary K concentration depends on Na status (Sjaastadt et al. 2003). Poutiainen (1968) reported that salivary $\mathrm{K}$ secretion decreased from $227 \mathrm{~g} \mathrm{~d}^{-1}$ in cows receiving no supplementary $\mathrm{NaCl}$ to $40-50 \mathrm{~g} \mathrm{~d}^{-1}$ when $50-100 \mathrm{~g} \mathrm{~d}^{-1}$ of $\mathrm{NaCl}$ was given.

\section{Calcium}

The proportional $\mathrm{Ca}$ absorption will decrease as dietary $\mathrm{Ca}$ intake exceeds the requirements of the tissues for absorbed Ca (NRC 2001). In the present study, the supply of $\mathrm{Ca}$ was below the requirement (MTT 2006) for the cows consuming the control diet and SBE diets, which would allow to truly determine the efficiency of $\mathrm{Ca}$ absorption. In spite of this, the intercept of the regression between the intake and faecal output was negative which has no biological meaning (faecal output can not be negative). The negative intercept between $\mathrm{Ca}$ intake and faecal output (or positive intercept between intake and absorption) suggests that the incremental $\mathrm{Ca}$ derived from increased silage DM intake and from protein supplements was absorbed with a lower efficiency. The mean Ca digestibility of 0.34 was slightly higher than that of 0.30 in the study of Khorasani et al. (1997). 
Vol. 15 (2006): 219-234.

The mean apparent absorption of $\mathrm{Ca}$ from the rumen was $2.5 \mathrm{~g} \mathrm{~d}^{-1}$, but the true absorption is higher due to salivary secretion. According to Yano et al. (1991), Ca concentration in mixed saliva ranges from 16 to $30 \mathrm{mg} \mathrm{l}^{-1}$. Therefore, we could speculate that approximately $6 \mathrm{~g}$ of $\mathrm{Ca}$ were secreted into the rumen via saliva, when calculated using salivary secretion estimated from omasal $\mathrm{Na}$ flow $\left(267 \mathrm{ld} \mathrm{d}^{-1}\right)$. The slope of the regression between Ca intake and omasal flow (0.93) suggested that proportionally 0.07 of incremental Ca was absorbed from the rumen. In the study of Khorasani et al. (1997), the corresponding slope was markedly lower (0.51), which in addition to possible absorption of $\mathrm{Ca}$ from the omasum was related to a greater absorption in stomachs of cows fed lucerne silage high in $\mathrm{Ca}$. There is some disagreement in the literature on the site of $\mathrm{Ca}$ absorption. In the study of Khorasani and Armstrong (1992) the major site of $\mathrm{Ca}$ absorption was prior to the small intestine, whereas Yano et al. (1991) concluded in their review that the small intestine is the main absorptive site for $\mathrm{Ca}$, which is also supported by our data.

\section{Magnesium}

Apparent Mg digestibility (mean 0.218) compares well with the values of 0.244 and 0.202 reported by Rahnema et al. (1994) and Khorasani et al. (1997). The strong positive relationships between $\mathrm{Mg}$ intake and omasal and faecal outputs indicate that intake rather than feed characteristics regulated Mg excretion. Magnesium absorption occurred in the rumen, which is in accordance with earlier reports (Khorasani and Armstrong 1990, 1992, Rahnema et al. 1994, Khorasani et al. 1997).

The net secretion of $\mathrm{Mg}$ into the small intestine $\left(0.5 \mathrm{~g} \mathrm{~d}^{-1}\right)$ was marginal compared with the values of 3.7 and $4.5 \mathrm{~g} \mathrm{~d}^{-1}$ in earlier studies using duodenal sampling (Rahnema et al. 1994, Khorasani et al. 1997). The difference may be attributed to different sampling sites, since considerable $\mathrm{Mg}$ absorption was found in the omasum of young cattle (Edrise and Smith 1986, Edrise et al. 1986). The relationship between omasal $\mathrm{Mg}$ flow $(\mathrm{X})$ and fae- cal $\mathrm{Mg}$ excretion $\left(\mathrm{Y}=3.6 \pm 2.6+0.91 \pm 0.07 \mathrm{X} ; \mathrm{R}^{2}\right.$ $=0.87$ ) indicates that $3.6 \mathrm{~g} \mathrm{~d}^{-1} \mathrm{Mg}$ was secreted post omasum and that proportionally 0.09 of $\mathrm{Mg}$ flowing into the omasum was absorbed, most likely in the omasum.

\section{Phosphorus}

In the present study, the intercept of the regression between $\mathrm{P}$ intake and omasal flow was almost equal to the mean $\mathrm{P}$ intake ( 85 vs. $79 \mathrm{~g} \mathrm{~d}^{-1}$ ) whereas in the studies of Rahnema et al. (1994) and Khorasani et al. (1997) the intercept of regression was markedly lower than intake. The difference of $89 \mathrm{~g}$ $\mathrm{d}^{-1}$ between $P$ flow and intake was markedly higher than the corresponding values of 28 and $48 \mathrm{~g} \mathrm{~d}^{-1}$ in other studies (Rahnema et al. 1994, Khorasani et al. 1997). This discrepancy may be associated to digesta sampling sites. Appreciable absorption of $\mathrm{P}$ between the reticulum and duodenum, presumably from the omasum, has been demonstrated (Edrise and Smith 1986). It has been suggested that daily salivary secretion might be calculated by the difference between daily P intake and flow into the duodenum (Scott and McLean 1981), but the data presented by Yano et al. (1991) indicated that the sum of dietary and salivary $\mathrm{P}$ considerably exceeds the $\mathrm{P}$ flow at the duodenum, probably reflecting $\mathrm{P}$ absorption from the omasum. Therefore omasal sampling may allow a more accurate estimation of salivary flow than duodenal sampling due to absorption of $\mathrm{P}$ between reticulum and duodenum.

The range in salivary $\mathrm{P}$ concentration reported in the literature is rather wide ranging from $<100$ to 700 for cattle and from 400 to 700 for sheep as reviewed by Van Soest (1994), Karn (2001) and Pfeffer et al. (2005), and therefore analysis of $\mathrm{P}$ concentration in mixed saliva is a prerequisite for an estimation of salivary flow from the rumen. However, salivary P concentrations from 312-359 $\mathrm{mg} \mathrm{l}^{-1}\left(10.1\right.$ to $\left.11.6 \mathrm{mmol} \mathrm{l}^{-1}\right)$ calculated from salivary secretion estimated from the net $\mathrm{Na}$ and $\mathrm{P}$ secretion into the rumen are within the range reported for salivary P concentration of dairy cows (Karn 2001, Valk et al. 2002, Pfeffer et al. 2005). 
Tuori, M. et al. Omasal sampling to study mineral digestion

The present results do not support the suggestion of Khorasani et al. (1997) that P flow from the rumen is rather constant and that as $\mathrm{P}$ content of the diet increases, the salivary $\mathrm{P}$ secretion decreases. In contrast, increased $\mathrm{P}$ intake with protein supplemented diets resulted in small increases (slope 1.06) in the omasal $P$ flow indicating that salivary $\mathrm{P}$ secretion was not influenced by $\mathrm{P}$ intake. The slope slightly above 1.00 may reflect increased saliva production in response to increased silage DM intake when the protein supplements were fed.

The Lucas test indicated that $\mathrm{P}$ is not an ideal nutritional entity. The intercept was positive, which has no biological meaning, and the slope of regression had a high standard deviation. Positive intercepts may be interpreted as a low marginal digestibility of additional $\mathrm{P}$ and that the supply exceeds the requirements in cows consuming RSE diets, which resulted in reduced absorption (Wu et al. 2000, Pfeffer et al. 2005). Wu et al. (2000) suggested that apparent digestibility of $\mathrm{P}$ will be in the range of 0.45 to 0.50 when $\mathrm{P}$ is fed close to requirements. Lower values for apparent $\mathrm{P}$ digestibility would occur when $\mathrm{P}$ is fed in excess to requirements, because the gut attempts to regulate $\mathrm{P}$ uptake according to requirements and to maintain homeostasis.

The Lucas equation estimated using only the SBE containing diets was biologically more meaningful than the overall equation: Digestible $\mathrm{P}$ ( $\mathrm{g}$ $\left.\mathrm{kg}^{-1} \mathrm{DM}\right)=0.62 \times \mathrm{P}\left(\mathrm{g} \mathrm{kg}^{-1} \mathrm{DM}\right)-0.72\left(\mathrm{R}^{2}=0.35\right)$. Although $\mathrm{R}^{2}$ value was low, the values for the intercept (-0.72) and slope of regression (0.62) are only slightly different from the NRC (2001) recommendation for the maintenance requirement (1 $\mathrm{g} \mathrm{kg}^{-1} \mathrm{DM}$ intake) and true absorption coefficient of dietary $\mathrm{P}(0.70)$, suggesting that these diets ( $\mathrm{P}$ concentration 3.3 to $\left.3.6 \mathrm{~g} \mathrm{~kg}^{-1} \mathrm{DM}\right)$ met the $\mathrm{P}$ requirements of cows producing on average $33 \mathrm{~kg}$ milk per day.

Dietary P concentration and P intake $\left(3.3 \mathrm{~g} \mathrm{~kg}^{-1}\right.$ $\mathrm{DM}$ and $65 \mathrm{~g} \mathrm{~d}^{-1}$ ) of the cows fed the control diet were below the requirements calculated according to NRC (2001) system, but P concentration was higher than 3.0-3.1, which is considered marginal (Satter 2003). Although the control diet was slightly marginal in the $\mathrm{P}$ supply, the $\mathrm{P}$ availability from soybean expeller (0.62) was clearly lower than the values (0.90) found in animals fed below the requirements (Kincaid and Rodehutscord 2005, Pfeffer et al. 2005).

A low true digestibility of incremental P mainly derived from rapeseed could be related to the low availability of $\mathrm{P}$ in rapeseed. However, in the study of Rodehutscord and Pfeffer (unpublished, ref. Kincaid and Rodehutscord 2005) faecal P output remained unchanged indicating a high availability of rapeseed $\mathrm{P}$.

True digestibility of omasal $\mathrm{P}$ estimated as a regression between the phosphorus absorbed in the lower tract and omasal P flow was markedly higher than the corresponding slope between total $\mathrm{P}$ absorption and $\mathrm{P}$ intake (0.46 vs. 0.26). This suggests that salivary $\mathrm{P}$ was absorbed with greater efficiency than dietary P (Challa et al. 1989, NRC 2001, p. 110). The regression for the omasal $P$ absorption $\left(\mathrm{g} \mathrm{d}^{-1}\right)$ in the lower tract, which included $\mathrm{P}$ intake and salivary $\mathrm{P}$ (omasal $\mathrm{P}$ flow $-\mathrm{P}$ intake), was as follows: $\mathrm{P}$ absorbed $\left(\mathrm{g} \mathrm{d}^{-1}\right)=15 \pm 8.0+0.26 \pm 0.058$ Feed $\mathrm{P}+0.96 \pm 0.073$ Saliva $\mathrm{P}\left(\mathrm{RMSE}=3.2 ; \mathrm{R}^{2}=\right.$ $0.91)$. This equation suggests that salivary $P$ is efficiently reabsorbed. However, it is uncertain whether these coefficients are unbiased, because the intercept was positive.

\section{Sulphur}

The dietary requirement of sulphur for the ruminants is primarily to provide substrate to ensure maximal microbial protein synthesis. Sulphur intake was higher in cows fed RSE diets than in those fed SBE diets, which partly reflects higher concentrations of S-containing amino acids and other compounds in rapeseed than in soybean.

Dietary $\mathrm{S}$ is absorbed as sulphate and sulphide anions. Dietary $\mathrm{S}$ concentration of $1.94 \mathrm{~g} \mathrm{~kg}^{-1} \mathrm{DM}$ in cows fed the control diet was marginally below the NRC (2001) recommendation of $2.0 \mathrm{~g} \mathrm{~kg}^{-1}$ DM. Net absorption of $\mathrm{S}$ from the rumen even in cows fed the control diet suggests that NRC (2001) recommendation may overestimate the $\mathrm{S}$ requirement of rumen microbes. In the present study, the regression equation between $\mathrm{S}$ intake and omasal $\mathrm{S}$ 
Vol. 15 (2006): 219-234.

Fig. 1. Relationships between omasal nitrogen and sulphur (S) flow $\left(\mathrm{g} \mathrm{d}^{-1}\right)$ for the total data and separately for rapeseed (RSE) or soybean expeller (SBE).

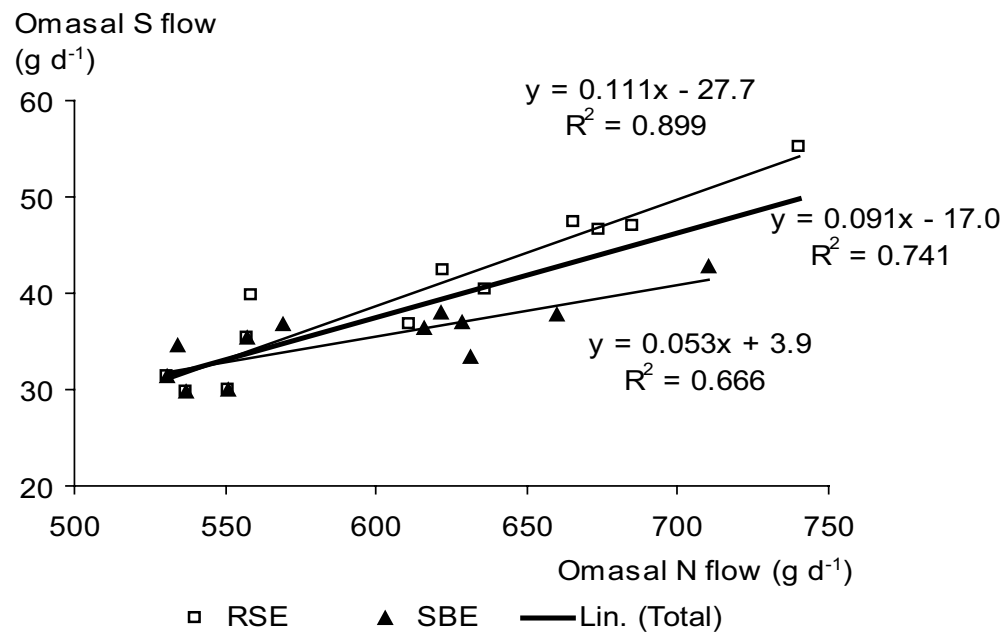

flow showed that proportionally 0.34 of $\mathrm{S}$ intake was absorbed in the rumen.

Omasal $\mathrm{S}$ and $\mathrm{N}$ flows were closely correlated (Fig. 1) indicating that a major proportion of $S$ flow from the rumen is associated with the protein flow. The slope of regression was markedly higher for the RSE diets than for the SBE diets (0.111 vs. $0.052 ; \mathrm{P}<0.01)$. This is partly attributed to the higher content of $\mathrm{S}$ containing amino acids in rapeseed than in soybean (MTT 2006), but most likely to the high concentration of non-amino S compounds in rapeseed.

Sulphur was the only mineral fraction that met the criteria of ideal nutritional entity, i.e. low standard deviation of the slope and zero or negative intercept, when the digestible amount was regressed against the total amount in the diet. In the present study based on individual data, the standard deviation of the slope was 0.040 and $\mathrm{R}^{2}$ was 0.945 . Using treatment mean data from published studies and from the present study showed a very close relationship between the concentrations of $\mathrm{S}$ and digestible $S$ in DM (Fig. 2) when a mixed model regression analysis was used to exclude the variation resulting from differences in experimental and analytical techniques between the laboratories (see St-Pierre 2001). The true $\mathrm{S}$ digestibility was $0.807 \pm 0.018$ and faecal metabolic and endogenous

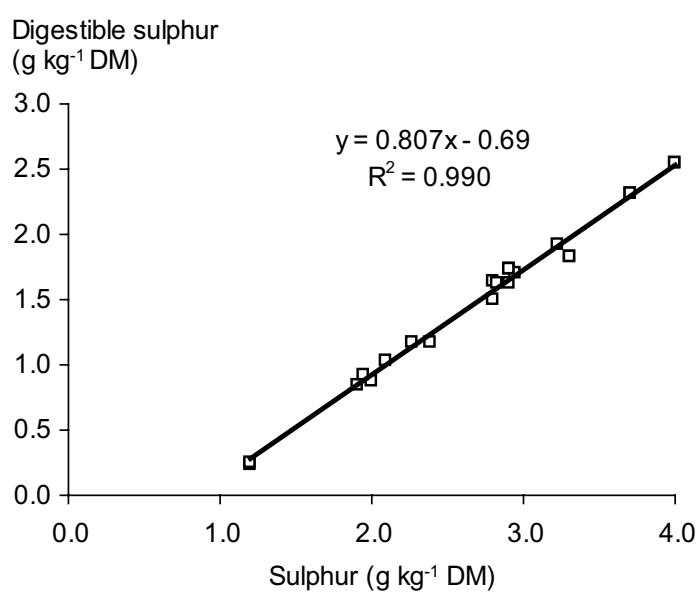

Fig. 2. Lucas test for sulphur $(\mathrm{N}=20)$. The values are adjusted for random study effect. Data from Muntifering et al. (1985), Spears et al. (1985), Puoli et al. (1991), Khorasani et al. (1997) and present study.

$\mathrm{S}$ fraction was $0.69 \pm 0.051 \mathrm{~g}$. The studies were conducted using sheep (Muntifering et al. 1985, Puoli et al. 1991), growing steers (Spears et al. 1985) and lactating dairy cows (Khorasani et al. 1997, present study). The dietary S concentrations were manipulated by elementary S (Muntifering et al. 1985), sodium sulphate (Puoli et al. 1991), sul- 
Tuori, M. et al. Omasal sampling to study mineral digestion

phur fertilization (Spears et al. 1985), forage type (Khorasani et al. 1997) and protein supplementation (present study). Even when the random study effect was excluded from the model, the $\mathrm{R}^{2}$ value remained high (0.96) and the standard deviation of true $\mathrm{S}$ digestibility relatively low (0.030).

\section{Conclusions}

Omasal sampling technique provides an experimental tool to investigate mineral metabolism in the reticulo-rumen, and if used in duodenally cannulated animals, net pre-intestinal mineral absorption can be separated between reticulo-rumen and omasum-abomasum. Appropriate marker techniques are required for estimation of mineral metabolism in the fore-stomachs. Both $\mathrm{Na}$ and $\mathrm{P}$ secretions into the rumen were markedly higher than in studies conducted using duodenally cannulated animals due to marked absorption of these minerals from the omasum. Magnesium was mainly absorbed from the rumen while $\mathrm{K}$ and $\mathrm{Ca}$ from the small intestine. The Lucas test demonstrated a uniform behaviour of sulphur over a wide range of diets. Net absorption of sulphur from the rumen suggests that sulphur is unlikely to be limiting factor for rumen microbial synthesis when diets based on silage and cereal grains are fed. The results indicate that no supplementary $\mathrm{P}$ and $\mathrm{Mg}$ are required in cows fed diets similar to the current experiment, especially if rapeseed feeds are used as protein supplements.

\section{References}

Ahvenjärvi, S., Vanhatalo, A., Huhtanen P. \& Varvikko, T. 1999. Effects of supplementation of a grass silage and barley diet with urea, rapeseed meal and heat-moisture treated rapeseed cake on milk production and omasal digesta flow in lactating dairy cows. Acta Agricuturae Scandinavica, Section A Animal Science 49: 179-189.

Ahvenjärvi, S., Vanhatalo, A., Huhtanen, P. \& Varvikko, T. 2000. Determination of forestomach digestion in lactat- ing dairy cows by omasal or duodenal sampling. British Journal of Nutrition 83: 67-77.

Ahvenjärvi, S., Vanhatalo, A., Shingfield, K.J. \& Huhtanen, P. 2003. Determination of digesta flow entering the omasal canal of dairy cows using different marker systems. British Journal of Nutrition 90: 41-52.

AOAC 1990. Official methods of analysis. Association of Official Analytical Chemists, Inc., Arlington, VA. 1298 p. ISBN 0-935584-42-0

Carpenter, S.R., Caraco, N.F., Correll, D.L., Howarth, R.W., Sharpley, A.N. \& Smith, V.H. 1998. Nonpoint pollution of surface waters with phosphorus and nitrogen. Ecological Applications 8: 559-568.

Challa, J., Braithwaite, G.D. \& Dhanoa, M.S. 1989. Phosphorus homeostasis in growing calves. Journal of Agricultural Science, Cambridge 112: 217-226.

Choi, C.W., Ahvenjärvi, S., Vanhtalo, A., Toivonen, V. \& Huhtanen, P. 2002. Quantification of the flow of soluble nonammonia nitrogen entering the omasal canal of dairy cows fed grass silage based diets. Animal Feed Science and Technology 96: 203-220.

Church, D.C. 1988. The ruminant animal. Digestive physiology and nutrition. A Reston Book. Prentice Hall, Englewood Cliffs, NJ, USA 1988. 564 p.

Edrise, B.M. \& Smith, R.H. 1986. Exchanges of magnesium and phosphorus at different sites in the ruminant stomach. Archives of Animal Nutrition 36: 1019-1027.

Edrise, B.M., Smith, R.H. \& Hewitt, D. 1986. Exchanges of water and certain water-soluble minerals during passage of digesta through the stomach compartments of young ruminating bovines. British Journal of Nutrition 55: 157-167.

Ekholm, P., Rekolainen, S., Antikainen, S. \& Grönroos, J. 1999. Impact of agricultural pollution on water systems. Country paper of Finland. In: van de Kraats, J.A. (ed.). Farming without harming. The impact of agricultural pollution on water systems. 5th technical reviewEuraqua, 7-8 October 1998, Oslo, Norway. Lelystad. p. $45-56$.

Engelhardt, W.V. \& Hauffe, R. 1975. Role of omasum in absorption and secretion of water and electrolytes in sheep and goats. In: McDonald, I.W. \& Warner, A.C.I. (eds.). Digestion and metabolism in ruminant. New England University Press, Armidale, Australia. p. 216230.

France, J. \& Siddons, R.C. 1986. Determination of digesta flow by continuous marker infusion. Journal of Theoretical Biology 121: 109-121.

Granlund, K., Räike, A., Ekholm, P., Rankinen, K. \& Rekolainen, S. 2005. Assessment of water protection targets for agricultural nutrient loading in Finland. Journal of Hydrology 304: 251-260.

Huhtanen, P., Brotz, P.G. \& Satter, L.D. 1997. Omasal sampling technique for assessing fermentative digestion in the forestomach of dairy cows. Journal of Animal Science 75: 1380-1392.

Joblin, N.K. \& Lee, J. 1990. Movement of nutrient and nonnutrient elements in the liquid phase in sheep rumen. Journal of Animal Science 68: 2067-2074.

Karn, J.F. 2001. Phosphorus nutrition of grazing cattle: a review. Animal Feed Science and Technology 89: 133135. 
Vol. 15 (2006): 219-234.

Kincaid, R.I. \& Rodehutscord, M. 2005. Phosphorus metabolism in the rumen. In: Pfeffer, E. \& Hristov, A.N. (eds.). Nitrogen and phosphorus nutrition of cattle. CABI Publishing. p. 187-194.

Khorasani, G.R. \& Armstrong, D.G. 1990. Effect of sodium and potassium level on the absorption of magnesium and other macrominerals in sheep. Livestock Production Science 24: 223-235.

Khorasani, G.R. \& Armstrong, D.G. 1992. Calcium, phosphorus and magnesium sabsorption and secretion in the bovine digestive tract as influenced by dietary concentration of these elements. Livestock Production Science 31: 271-286.

Khorasani, G.R., Janzen, R.A., McGill, W.B. \& Kennelly, J.J. 1997. Site and extent of mineral absorption in lactating cows fed whole-crop cereal grain silage or alfalfa silage. Journal of Animal Science 75: 239-248.

Lucas, H.L. 1964. Stochastic elements in biological models; their sources and significance. In: Garland, J. (ed.). Stocastic models in medicine and biology. University of Wisconsin Press, Madison, USA. 355 p. (Ref. Van Soest 1994).

Luh Huang, C.-Y. \& Schulte, E.E. 1985. Digestion of plant tissue for analysis by ICP emission spectrometry. Communications in soil science and plant analysis 16: 943958.

Maekava, M., Beauchemin, K.A. \& Christensen, D.A. 2002. Effect of concentrate level and feeding management on chewing activities, saliva production, and ruminal $\mathrm{pH}$ of lactating dairy cows. Journal of Dairy Science 85: 1165-1175.

Mäkelä, A. 1956. Studies on the question of bulk in the nutrition of farm animals with special reference to cattle. Acta Agralia Fennica 85: 1-130.

MTT 2006. Rehutaulukot ja ruokintasuositukset (Feed tables and feeding recommendations). Jokioinen: MTT Agrifood Research Finland. Updated 14 Feb 2006. Cited 26 June 2006. Available on the Internet: http://www. agronet.fi/rehutaulukot/. URN:NBN:fi-fe20041449.

Muntifering, R.B., Smith, S.I. \& Boling, J.A. 1985. Effect of elemental sulphur supplementation on digestibility and metabolism of early vegetative and fall-accumulated fescue by wethers. Journal of Animal Science 59: 1100-1105.

Nash, D.M. \& Haygarth, P.M. 2005. Grassland productivity and water quality: a 21st Century issue. In: McGilloway, D.A. (ed.). Grassland: a global resource. Wageningen Academic Publishers, The Netherlands. p. 239-249.

NRC 2001. Nutrient requirements of dairy cattle. National Research Council. 7th revised edition. National Academy Press, Washington, DC. 381 p.

Pfeffer, E., Beede, D.K. \& Valk, H. 2005. Phosphorus metabolism in ruminants and requirements of cattle. In: Pfeffer, E. \& Hristov, A.N. (eds.). Nitrogen and phosphorus nutrition of cattle. CABI Publishing. p. 195-231.

Poutiainen, E. 1968. Factors influencing the flow of fluid, saliva and some cations through the reticulo-omasal orifice of the cow. Annales Agriculturae Fenniae 7, Suppl. 3. 66 p.

Puoli, J.R, Jung, G.A. \& Reid, R.L. 1991. Effects of nitrogen and sulphur on digestion and nutritive quality of warm season grass hays for cattle and sheep. Journal of Animal Science 69: 843-852.

Rahnema, S., Wu, Z., Ohajuruka, O.A., Weiss, W.P. \& Palmquist, D.L. 1994. Site of mineral absorption in lactating dairy cows fed high-fat diets. Journal of Animal Science 72: 229-235.

Reynal, S.M., Broderick, G.A., Ahvenjärvi, S. \& Huhtanen, P. 2003. Effect of feeding protein supplements of differing degradability on omasal flow of microbial and undegraded protein. Journal of Dairy Science 86: 12921305.

SAS Institute Inc. 1999. SAS/STAT, User's guide Version 8, SAS Institute Inc., Cary, NC, USA.

Satter, L.D. 2003. Phosphorus management in cattle production systems. In: Garnsworthy, P.C. \& Wiseman, J. Recent advances in animal nutrition 2003. Nottingham University Press. p. 158-173.

Scott, D. \& McLean, A.F. 1981. Control of mineral absorption in ruminants. Proceedings of the Nutrition Society 40: 257-266.

Shingfield, K., Ahvenjärvi, S., Toivonen, V., Ärölä, A., Nurmela, K.V.V., Huhtanen, P. \& Griinari, J.M. 2003. Effect of dietary fish oil on biohydrogenation of fatty acids and milk fatty acid content in cows. Animal Science 77: 165-179.

Spears, J.W., Burns, J.C. \& Hatch, P.A. 1985. Sulphur fertilisation of cool season grasses and effect on utilisation of minerals, nitrogen and fibre by steers. Journal of Dairy Science 68: 347-355.

Sjaastad, Ø., Hove, K. \& Sand, O. 2003. Physiology of domestic animals. Scandinavian Veterinary Press, Oslo. $735 \mathrm{p}$.

St-Pierre, N.R. 2001. Integrating quantitative findings of from multiple studies using mixed model methodology. Journal of Dairy Science 84: 741-755.

Valk, H., Šebek, L.B.J. \& Beynen, A.C. 2002. Influence of phosphorus intake on excretion and blood plasma and saliva concentrations of phosphorus in dairy cows. Journal of Dairy Science 85: 2642-2649.

Valpasvuo-Jaatinen, P., Rekolainen, S. \& Latostenmaa, H. 1997. Finnish agriculture and its sustainability: environmental impacts. Ambio 26: 448-455.

Van Soest, P.J. 1994. Nutritional ecology of the ruminant. Second Edition. Comstock Publishing Associates, Cornell University Press, Ithaca and London. $476 \mathrm{p}$.

Wu, Z., Satter, L.D. \& Sojo, R. 2000. Milk production, reproductive performance, and feacal excretion of phosphorus by dairy cows fed three amounts of phosphorus. Journal of Dairy Science 83: 1028-1041.

Yano, F., Yano, H. \& Breves, G. 1991. Calcium and phosphorus metabolism in ruminants. In: Tsuda, T. et al. (eds.). Physiological aspects of digestion and metabolism in ruminants. Academic Press, Inc. p. 455-482. 
Tuori, M. et al. Omasal sampling to study mineral digestion

\title{
SELOSTUS
}

\section{Satakertanäytteenottomenetelmä soveltuu lypsylehmien kivennäisaineiden sulatuksen tutkimiseen}

\author{
Mikko Tuori, Marketta Rinne, Aila Vanhatalo ja Pekka Huhtanen \\ Maa- ja elintarviketalouden tutkimuskeskus ja Helsingin yliopisto
}

Fysiologisessa kokeessa selvitettiin rypsi- ja soijapuristeruokinnan vaikutusta lypsylehmien kivennäisaineiden eli natriumin, kaliumin, magnesiumin, fosforin ja rikin sulatukseen. Lehmien päivittäinen väkirehuannos oli 9 $\mathrm{kg}$, ja se koostui ohran ja kauran seoksesta, jota korvattiin rypsi- tai soijapuristeella kahdella käyttömäärällä siten, että väkirehujen valkuaispitoisuudet olivat 130 , 180 ja 230 g/kg kuiva-ainetta. Koeruokintoja oli yhteensä viisi. Lehmät söivät vapaasti säilörehua, joka sisälsi puolet puna-apilaa ja puolet timotei-nurminataa. Lisäksi lehmille annettiin suolaa ja hivenainelisä, mutta ei muita kivennäislisiä. Pötsisulavuus määritettiin satakertanäytteenottomenetelmällä, ja kokonaissulavuus sonnan kokonaiskeruun avulla.

Muiden kivennäisten paitsi natriumin saanti lisääntyi valkuaislisän myötä, ja rypsipuristetta saaneiden leh- mien kivennäisten saanti oli yleensä suurempi kuin soijapuristetta saaneiden. Magnesiumin imeytyminen tapahtui pääasiassa pötsi-verkkomahasta, mutta kalsium, fosfori, natrium ja kalium imeytyivät pääasiassa pötsiverkkomahan jälkeen. Rikkiä imeytyi sekä pötsi-verkkomahasta että sen jälkeen. Rikin nettoimeytyminen pötsi-verkkomahasta osoittaa säilörehusta ja viljasta koostuvien ruokintojen sisältäneen riittävästi rikkiä pötsimikrobien tarpeeseen. Suuri satakertaan virtaava natriumin ja fosforin määrä kertovat näiden kivennäisten runsaasta erityksestä syljen mukana. Satakerta on tärkeä kivennäisten, erityisesti natriumin ja fosforin imeytymispaikka. Tulokset osoittavat myös, että lisäfosforin ja -magnesiumin tarvetta ei ollut kokeessa käytetyillä viljasäilörehuruokinnoilla käytettäessä rypsirehuja valkuaislähteenä. 